\title{
Study on the influence of political connections on real estate firms' starting business ventures--with resource acquisition playing an intermediary role
}

\author{
Zhao Wang ${ }^{1, a}$, Xiaobing Liu $^{2}$ \\ ${ }^{1}$ Dalian University of Technology, Chinese \\ ${ }^{2}$ Dalian University of Technology, Chinese \\ adl_202@163.com
}

Key words: Political connection, starting new business ventures, resource acquisition

\begin{abstract}
Under the circumstances of China's economic transformation, the real estate industry is facing an uncertain future which impels many real estate firms to seek new business ventures. Based on a survey, this study analyses the influence that political connections have on real estate companies' chances to start new business ventures by using the Mplus software to establish structure model and examines the intermediary role of resource acquisition. We find that good political connections help real estate companies identify the resource endowment that they have and increase the possibility of acquiring external resources and therefore the possibility of new ventures so that they can achieve better entrepreneurial performance.
\end{abstract}

\section{Introduction}

With China's economic transformation upgrading and the regulation of economy normalizing, the original developing patterns are hard to continue and the crisis awareness of real estate companies is increasing day by day. As a result, a large number of such companies have transformed and initiated a hot revolution of starting new business ventures. But the complicated external and internal environment caused by the transformation of economy brings much uncertainty to real estate companies that tend to start a new undertaking. How to identify entrepreneurial opportunities so as to achieve entrepreneurial goals is a question that each entrepreneur needs to think over. In actual operation, enterprises often evaluate their entrepreneurial opportunities according to the resource endowment they have and they can acquire from the outside. More and more scholars have come to realize that enterprises' social resources are playing a significant role in promoting their entrepreneurial behaviors.

China is implementing socialist market economy, so the government intervention to economy and regulation of economy are both stronger than those in mature market-oriented economies. The government has a large quantity of scarce resources and tends to distribute these resources to state-owned enterprises, which makes private enterprises face unequal competition in their effort to get these scarce resources. Institutional theories believe that people replace formal institutions with interpersonal guan xi when the market is lacking in formal institutions. In consequence, private enterprises have the motivation to acquire the resources and information controlled by the government by establishing political connections. Can political connections bring enterprises the key resources and information concerning their entrepreneurial opportunities? Will these resources and information influence the choice that real estate firms make to start new business ventures and the operational efficiency afterwards? To answer those questions, this paper intends to bring forward research hypotheses by establishing corresponding theoretical models and use the data from questionnaires for empirical analysis to learn about to some degree the relationship between 
political connections and real estate companies' starting new business ventures.

\section{Research summary and research hypothesis}

\subsection{Research summary}

Political connections mean that enterprises get involved in the government activities and then influence the government's public decisions in either open or hidden ways. Plenty of facts and studies suggest that political connection is a common phenomenon all over the world, especially in emerging market economies and developing countries. Meanwhile, the value of political connections is acknowledged by some scholars. Long Jianhui(2010) holds that it's a very effective way to establish political connections if enterprises in China want to grow under the imperfect institutional environment. A group of researchers led by Li Wei'an (2015) used the private enterprises between 2007 and 2010 as samples to study whether the political connections of these enterprises' actual controllers, chairmen of the board or managing directors and their charity donations were related to debt financing. They found that these private enterprises' doing charity was just a kind of reciprocal and strategic behavior towards the government to seek for debt financing. However, others such as Zhang Min hold different views. She finds that political connections will eventually impair the value of enterprises. The study of Zhang Tianshu, Chen Xinyuan and Huang Jun shows that the corporate performance and stock yields of companies with good political connections tend to decline after they are listed in the stock market. In conclusion, when real estate companies start new business ventures, whether political connections are to help or to plunder is yet to be confirmed.

\subsection{Research hypothesis}

1) Political connections and resource acquisition

China has a different social and economic institution from the West, and so are the forms of domestic political connections. Enterprises in our country acquire political connections mainly in the following four ways. Firstly, key tables like enterprise executives or shareholders seek positions in government departments. Second, government officials turn to business and become enterprise executives or shareholders. Third, enterprises employ agencies or individuals that play a part in government decisions as consultants. Fourth, relatives or friends of those key tables such as enterprise executives or shareholders have a position in government departments. The former two are explicit and easy to notice while the latter are implicit. As a result, we refer to political connections as explicit and implicit ones.

Political connections as a tool of interpersonal relationship enable enterprises to get various information and resource advantages as well in the following ways. First, they help enterprises acquire information from the "insiders". Second, enterprises can obtain tax preference and government subsidies easily. Third, political connections help enterprises acquire favorable financial terms. Fourth, enterprises with political connections are likely to break government regulatory barriers. To sum up, political connections help enterprises obtain all kinds of information and resources and better carry out their business strategies so as to improve their corporate performance. Based on the above, our assumptions are as follows.

Assumption 1: Political connections have positive influence on resource acquisition.

2) Resource acquisition and real estate firms' starting new business ventures

Technology is upgrading faster at present than any time in the past, which follows the continuous changes of enterprises' competitive environment. More and more enterprises have realized that they must have the ability to continuously acquire and then take advantage of external 
resources if they want to establish and sustain their competitive advantages. For example, if they can obtain new manufacturing techniques from the outside, the time and cost they need for research and development will be reduced to some degree. New production opportunities will arise and the competitiveness of corporate products will be improved as well. Based on the above, we have the second assumption.

Assumption 2: Resource acquisition have positive effect on real estate firms' starting new business ventures.

In conclusion, only with the support of rich and available resources can entrepreneurial activities be implemented on the basis of the existing strategies. When starting new business ventures, managers of enterprises must connect and integrate internal resources and seek some critical resources from the outside to make sure resources play a better part in the process. For example, if enterprises can get knowledge from the outside, they can reduce to some degree the time and money they have to spend on their own research and development. Political connections play an active part in helping enterprises acquire both knowledge and asset resources such as policies, technology information, land, bank loans and tax preference.

Combine Assumption 1 and Assumption 2 and we have the following assumption.

Assumption 3: Resource acquisition plays an intermediary role in the relationship between political connections and real estate firms' starting new business ventures.

\section{Research Design}

\subsection{Basic model building}

Political connections of enterprises as an important supplement of the market mechanism in economic transformation influence directly or indirectly the external resource acquisition and therefore influence the corporate performance. Based on this, this paper establishes a research framework with resource acquisition as a mediator, which is shown in the following picture.

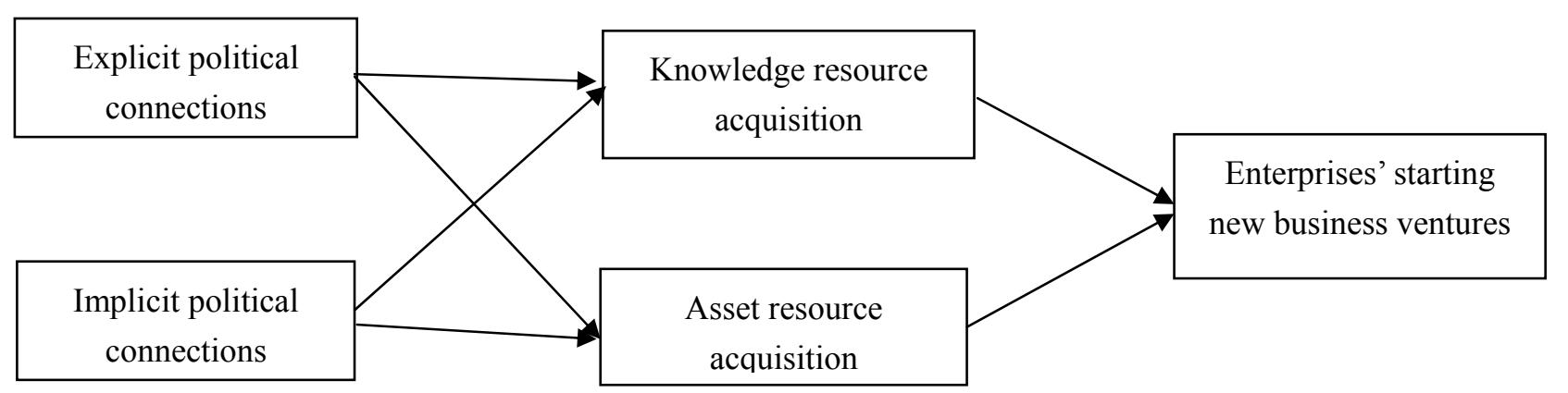

\subsection{Collection of samples and data}

The research data of this paper comes from a survey done in the following three ways. First, we handed out questionnaires to the concerning enterprises in the three northeast provinces. Second, we entrusted municipal and provincial construction offices to distribute the questionnaires to the enterprises to be investigated. Also, we get information from internet forums or the SO JUMP, which is a professional online investigation website. Totally, 273 out of 320 questionnaires were recovered, among which 223 were valid. From the positions of the interviewees and the investigated enterprises' scale and date of establishment, we can see the samples are distributed evenly and quite representative. 


\subsection{Measurement of variables}

1) Political connections. We evaluate political connections with administrative ranks of those working in government departments, marking from 5 to 1, which respectively stands for Provincial level, Bureau-Director level, Division-Head level, Section-Head level and staff-member level. The higher the mark is, the stronger political connections are.

2) Resource acquisition. We classify resources as knowledge and asset ones. In the questionnaire, resource acquisition is measured by Likert Scale with 1 representing "totally disagree" and 5 referring to "totally agree".

3) Enterprises' starting new business ventures. This is the dependent variable of our research. When we study it, we consider both financial and non-financial indexes, mainly the profitability, growth and satisfaction ones, all of which are used to evaluate the corporate performance.

\subsection{Credibility and validity of samples}

1) Credibility analysis

Credibility shows whether the results of the scale are reliable. It is universally believed that the samples are reliable if the coefficient of Cronbach's Alpha (a) is above 0.7. Using the software SPSS22.0 to calculate, we find the coefficient of each latent variable is beyond 0.9 , which means the survey is reliable.

2) Validity analysis

Validity is about how much a scale shows what the researchers want to measure. We use the confirmatory factor analysis of Mplus to measure the content and the construct validity of the scale. After rectifying the collinearity, the model fitting indices are shown in the table, from which we can know that the percentage between chi-square and degree of freedom is 2.889 , which is acceptable. CFI and TLI are also acceptable and so are REMSA and SRMR, which are below 0.1 and 0.08 respectively. In one word, the degree of model fitting is relatively good.

\section{Analysis and results}

\subsection{Descriptive statistical analysis}

Before Structural Equation Modeling (SEM), this paper first make the descriptive statistics according to the related variables. The purpose is to study the statistical characteristics and relationship of each variable. The results are shown in the table 1.

Table 1: The statistical characteristics of the sample enterprise

\begin{tabular}{|c|c|c|c|c|c|c|c|}
\hline Characteristics & Categories & Frequency & Frequency & Characteristics & Categories & Frequency & Frequency \\
\hline \multirow{4}{*}{$\begin{array}{c}\text { Types of } \\
\text { ownership }\end{array}$} & $\begin{array}{c}\text { Private } \\
\text { Enterprise }\end{array}$ & 163 & $73.09 \%$ & \multirow{4}{*}{$\begin{array}{l}\text { Registered } \\
\text { capital }\end{array}$} & $\begin{array}{c}\text { Below } 5 \\
\text { million } \\
\quad(¥)\end{array}$ & 22 & $9.87 \%$ \\
\hline & $\begin{array}{l}\text { Collective } \\
\text { Enterprise }\end{array}$ & 7 & $3.14 \%$ & & $\begin{array}{l}\text { 5-10 million } \\
\quad(¥)\end{array}$ & 37 & $16.59 \%$ \\
\hline & $\begin{array}{c}\text { Solely } \\
\text { State-owned } \\
\text { Enterprise }\end{array}$ & 7 & $3.14 \%$ & & $\begin{array}{c}\text { 10-30 million } \\
\quad(¥)\end{array}$ & 41 & $18.39 \%$ \\
\hline & $\begin{array}{c}\text { State-controll } \\
\text { ed } \\
\text { Enterprises }\end{array}$ & 37 & $16.59 \%$ & & $\begin{array}{c}\text { 30-100 million } \\
\text { ( } ¥)\end{array}$ & 82 & $36.77 \%$ \\
\hline
\end{tabular}




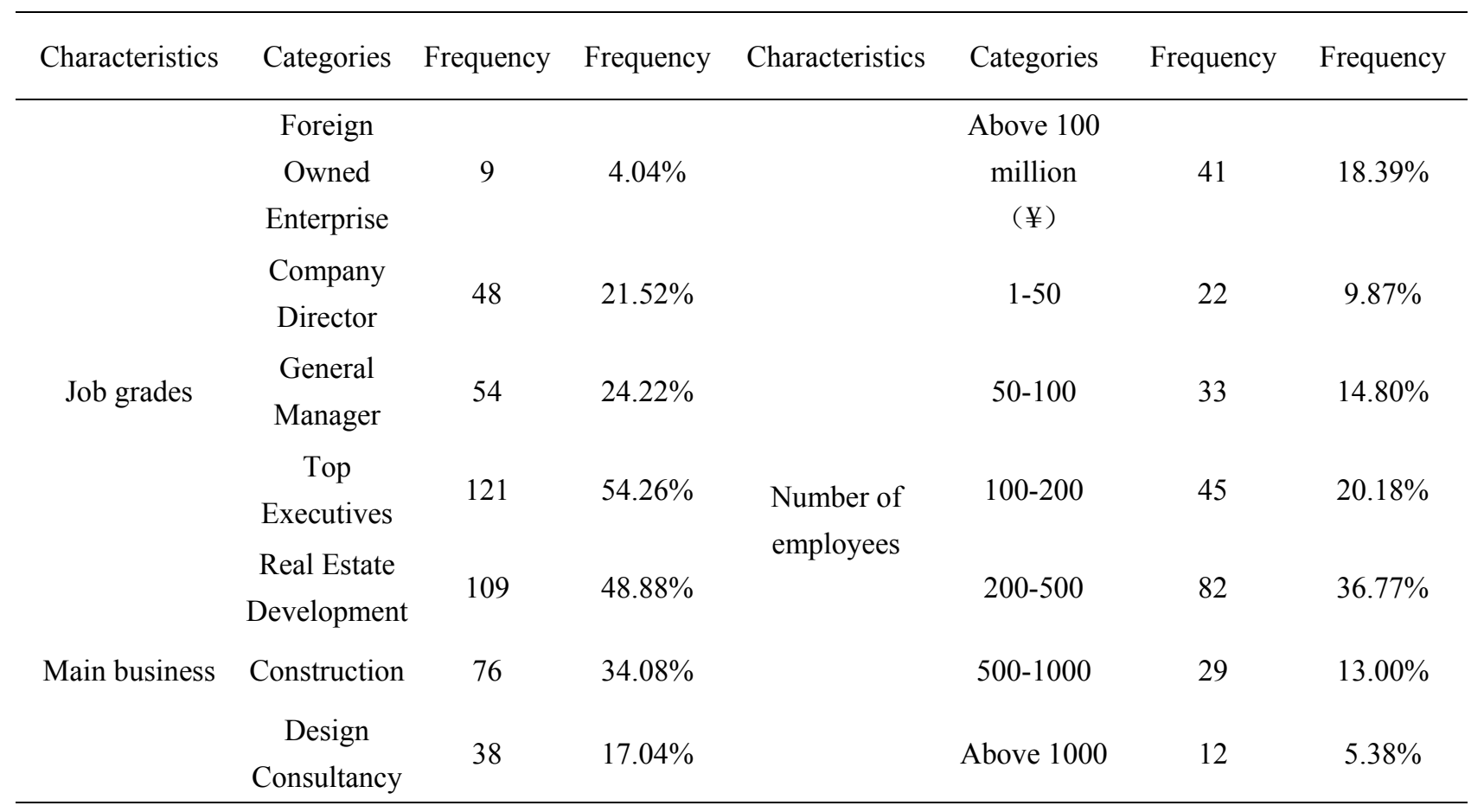

\subsection{Main effects analysis}

This study adopts Structural Equation Modeling (SEM) which can handle multiple dependent variables and allow the measure errors of independent variables and dependent variables. Besides, the method also can estimate the measurable relationships and structural relationships between factors. It allows more flexible settings of measurement models and estimate the fitting degree of the whole model.

This study used Mplus7.0 software to construct a full model of the structural equation, calculate the path between the latent variables and ascertain the relationship between the latent variables.

Through structural equation analysis, the ratio of chi-square to the degree of freedom is 3.27 which is greater than 3.0. CFI and TLI were both higher than 0.9. Besides, RMESA $=0.101$, and $\mathrm{SRMR}=0.055$.The results are shown in the table 2. As a whole, the analysis of the structure equation is relatively ideal and reasonable.

Table 2: Indexes of Fitting

\begin{tabular}{|c|c|c|c|}
\hline \multirow{2}{*}{ Indexes } & \multicolumn{2}{|c|}{ Evaluation Criterion } & \multirow{2}{*}{ Fitting values } \\
\hline & Acceptable & Good & \\
\hline $\begin{array}{l}\text { Chi-square and Degree of freedom } \\
\text { (Chi-square/df) }\end{array}$ & $(3.0,5.0)$ & $<3.0$ & 3.27 \\
\hline Comparative fit index (CFI) & $\left(\begin{array}{ll}0.7, & 0.9\end{array}\right)$ & $>0.9$ & 0.967 \\
\hline TLI & $\left(\begin{array}{ll}0.7, & 0.9\end{array}\right)$ & $>0.9$ & 0.958 \\
\hline RMESA & $(0.08,0.1)$ & $<0.08$ & 0.101 \\
\hline SRMR & $<0.1$ & $<0.08$ & 0.055 \\
\hline
\end{tabular}

Through analyzing results of the relationship between latent variables (Table 3), dominant correlation of knowledge resources have obvious positive regressive relationship $(\mathrm{B}=0.615, \mathrm{P}=$ $0.000)$ which means the dominant association promotes the increase of knowledge resources. The recessive linkage and knowledge resources also show a clear positive regression relation $(\mathrm{B}=0.290$, 
$\mathrm{P}=0.000$ ) which indicating that the recessive linkage promotes the increase of knowledge resources. In the same way, political connection plays an obvious role in promoting the asset resources. Corporate entrepreneurship is associated with political resources, knowledge resources and asset resources. They all have obvious positive regression relationship with corporate entrepreneurship which indicates the knowledge resources and asset resources have an obvious role in promoting the company entrepreneurship. Explicit correlation and implicit correlation have obvious direct effect on the company's entrepreneurship. The direct effects are 0.218 and 0.143 respectively.

Table 3: Main Effect Path Coefficient Table

\begin{tabular}{ccccc}
\hline & Estimate & S.E. & Est./S.E. & P-Value \\
\hline $\begin{array}{c}\text { Asset resources } \leftarrow \text { Explicit political } \\
\text { connection }\end{array}$ & 0.615 & 0.070 & 8.751 & 0.000 \\
$\begin{array}{c}\text { Asset resources } \leftarrow \text { Implicit political } \\
\text { connection }\end{array}$ & 0.290 & 0.071 & 4.054 & 0.000 \\
$\begin{array}{c}\text { Knowledge resources } \leftarrow \text { Explicit political } \\
\text { association }\end{array}$ & 0.514 & 0.062 & 8.268 & 0.000 \\
$\begin{array}{c}\text { Knowledge resources } \leftarrow \text { Implicit political } \\
\text { association }\end{array}$ & 0.438 & 0.061 & 7.212 & 0.000 \\
$\begin{array}{c}\text { Corporate entrepreneurship } \leftarrow \text { Explicit } \\
\text { political connection }\end{array}$ & 0.206 & 0.093 & 2.223 & 0.026 \\
$\begin{array}{c}\text { Corporate entrepreneurship } \leftarrow \text { Implicit } \\
\text { political connection }\end{array}$ & 0.307 & 0.099 & 3.111 & 0.002 \\
$\begin{array}{c}\text { Corporate entrepreneurship } \leftarrow \text { Knowledge } \\
\text { resources }\end{array}$ & 0.218 & 0.100 & 2.178 & 0.029 \\
$\begin{array}{c}\text { Corporate entrepreneurship } \leftarrow \text { Asset } \\
\text { resources }\end{array}$ & 0.143 & 0.073 & 1.957 & 0.050 \\
\hline
\end{tabular}

\section{Research conclusion and enlightenment}

\subsection{Main conclusion}

We build a research framework consisting of political connections, resource acquisition and real estate firms' starting new business ventures and focus on the influence mechanism of political connections on real estate firms' starting new business ventures and the intermediary role of resource acquisition in the process. Based on our research, we have come into the following conclusions.

1) Political connections are important resources for real estate firms and can help them achieve better performance when starting new business ventures. Based on the interviews with the 223 key tables, including presidents, managers and other corporate executives, we find that political connections help real estate firms identity entrepreneurial opportunities and acquire better resource endowment and therefore accomplish better entrepreneurial performance. This in turn proves the point of resource-based theory that political connections, as an informal alternative mechanism in the market mechanism.

2) Resource acquisition plays a mediating role in the relationship between political relevance and two-time entrepreneurial performance of real estate companies. The strengthening of political association is helpful to the acquisition of knowledge and asset resources, and the acquisition of 
these two kinds of resources will help the real estate companies to carry out two times.

\subsection{Limitations and subsequent research prospect}

Under the circumstances of the economic transformation, our study focuses on the influence that political connections have on real estate firms' corporate performance when starting new business ventures. Though we have come to certain conclusions, there still exist some deficiencies.

1) The variables measured by Likert Scale has some inevitable deviations and defects, especially in the evaluation of implicit political connections, which adopted the method of subjective rating that might affect the accuracy and reliability of the data collected. As a result, more elaborate and objective methods should be used in future research.

2) Our study focuses more on the positive effects that political connections have on real estate firms' starting new business ventures than the negative ones. However, political connections are a double-edged sword. For real estate firms, are they to help or to plunder? In future research, we will take their dual characters into consideration and fully realize the influence they have on real estate firms' starting new business ventures.

3) In the mediating effect test, which is about the effect that knowledge resource acquisition has on implicit political connections and real estate firms' starting new business ventures, the P-Value is above 0.05 , the reason for which might be that the number of our interviewees is limited or that the sample data itself has certain limitations. This could be the issue of future research so as to further test the model's general significance.

\section{References}

[1] Feng Yanchao. A study on the relationship between political relation and tax burden of Chinese private enterprises [J]. Management Review, 2012, (6): 167-176.

[2] Wang Xiaolu, Fan Gang, Yu Jingwen. China Provincial Market Index report (2016) [R].2017.

[3] Zhang Jianqi. Political relations, institutional environment and entrepreneurial opportunities identification [J]. Journal of Northwestern University. 2015, (1): 124-131.

[4] Zhu Xiumei, Li Mingfang. The dynamic impact of entrepreneurial network characteristics on resource acquisition based on the evidence of China's transition economy [J]. Managing the World, 2011 (6): 105-116.

[5] Faccio M.Differences between politically connected and connected firms: A cross-country analysis [J].Financial Management, 2010, (3):90-928.

[6] UNSAL O, Hassan MK, Zurek D. Corporate lobbying, CEO political ideology and firm performance Journal of Corporate Finance, 2016, (38):126-149.

[7] Wow, Johan SA, Reimo. Institutional invest-tors, political connections, and the introduce of regulatory enforcement against corporate fraud. Journal of Business Ethics, 2016, (4):709-726. 